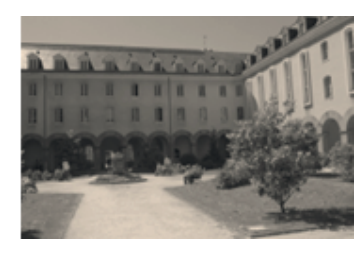

Public Choice, Social Choice, and Political

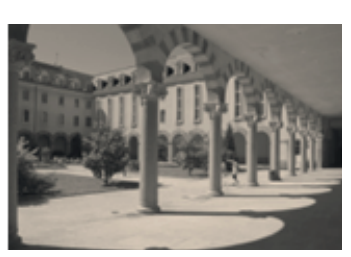

EcONOMY

Dennis C. MUELLER

University of Vienna
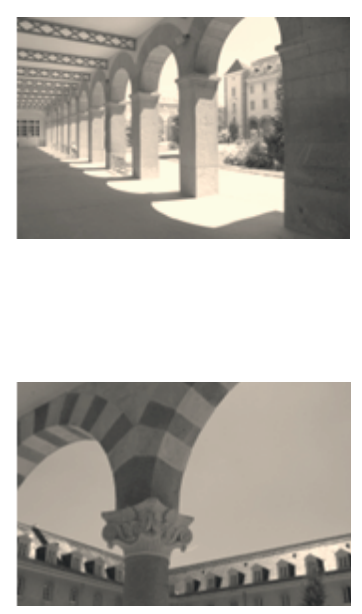

CONDORCET CENTER FOR POLITICAL ECONOMY UNIVERSITY OF RENNES 1 - CREM-CNRS

www.condorcet-center.fr 


\title{
Public Choice, Social Choice, and Political Economy
}

\author{
Dennis C. Mueller \\ University of Vienna
}

Prior to World War II, economists had by and large viewed the state as an institution for correcting market failures and redistributing income. The state was an institution to which advice was proffered - how should taxes be levied, how should externalities be corrected, what public goods should be supplied. Shortly after the war ended, however, economists began to study the process by which the state makes decisions. In a democracy, it was assumed that the state should make decisions that improve the welfare of its citizens. To do this, the state must determine what the citizens want. The democratic institutions of the state were supposed to provide the information required for this task.

The broad field of economics can be divided into positive theories, which seek to explain how markets function, and how firms and consumers behave, and theories about the normative properties of market processes - are there equilibria, are the outcomes Pareto optimal? The new theories concerning the democratic state also quickly separated into positive and normative inquiries. One of the more celebrated, normative contributions to this early literature was Kenneth Arrow's (1951) demonstration that no process for aggregating individual preferences - be it the market or the ballot box - can produce a social ordering that satisfies five, seemingly reasonable conditions. Kenneth May (1952) responded by showing that the simple majority rule did satisfy four normative conditions, although only for binary choices. With these two early and important contributions, a huge literature was launched that analyzes the normative properties of preference aggregation procedures.

The first contributions to the positive side of the literature were Duncan Black's 
(1948a, 1948b) analyses of the properties of voting rules, although one might regard the proof that the simple majority rule achieves an equilibrium with single-peaked preferences and a single-dimensional issue space as a normative finding.

Another pioneering contribution to the field was James Buchanan's (1954b) article contrasting the behavior of individuals in market exchange and when they vote. An action in the market has a direct and predictable impact on an individual's welfare - she gets to consume an apple instead of an orange. The consequence of her action when she votes depends on the actions of all other voters and is therefore less direct and predictable. This difference leads to decisions by voters, which are inherently less rational and often myopic. This distinction between the actions of individuals in the market, and when they vote, would reappear in different guises throughout Buchanan's career, e.g., (Brennan and Buchanan, 1985, Ch. 5).

Another important article by James Buchanan appeared in the same year and in the same journal, but must be regarded as a distinctly normative contribution. In a review of Arrow's book, Buchanan (1954a) criticized Arrow for employing an organic model of the state, and demanding that the state satisfy axioms that are associated with individual rationality, like transitivity of preference orderings. For Buchanan, collective action outcomes simply emerge from the individual choices of the participants in the democratic process. The normative justification for accepting the collective choices stems from the fact that the citizens have chosen the rules of the political game, and abide by them. This too was a theme that would often recur in Buchanan's later work.

Three years later, one of the most outstanding and frequently cited contributions to the positive analysis of democratic institutions would appear - Anthony Downs's An Economic Theory of Democracy. With great skill Downs showed that the economist's geometric tools could be used to illuminate how democratic processes operate, and so the spatial theory of 
voting was born. Although Downs's book must be regarded as a contribution to the literature describing how democratic institutions actually function, and how individual voters actually behave (they are rationally ignorant), Downs also appears to have had a normative objective in mind. An Economic Theory of Democracy was Downs's doctoral dissertation, and Kenneth Arrow was his supervisor. Downs entertained the idea that the competition for votes between political parties would achieve a kind of invisible hand solution to the collective action problem, thereby solving Arrow's paradox (Downs, 1957, pp.17-19). Under the assumptions that Downs made about the behavior of parties and voters, however, the problem of cycling - no equilibria - could not be avoided with issue spaces of more than one dimension. Downs's intuition about the normative consequences of party competition for votes arguably was substantiated with the advent of probabilistic voting models a generation later. $^{\mathrm{i}}$

Gordon Tullock's first major contribution to the positive analysis of voting institutions appeared in 1959. Tullock showed how the incentives individuals (in his example farmers) have to form majority coalitions and combine the provision of public goods with redistribution could result in an inefficient expansion of the public sector. Tullock's article would reappear as a chapter in The Calculus of Consent (1962) three years later. Given Buchanan's distaste for Arrow's normative approach to the state, one might have expected that The Calculus would be a purely positive analysis of democratic institutions. Much of it arguably was. In addition to Tullock's chapter on majority rule, there were other discussions of the properties of the simple majority rule, plus a seminal analysis of logrolling. The stated objective of the book, however, was to describe "what we think a State ought to be" (Buchanan and Tullock, 1962, p. 3, italics in original). Thus, as with Downs's An Economic Theory of Democracy, The Calculus of Consent must be deemed at least in part a normative exercise. 
William Riker's (1962) The Theory of Political Coalitions appeared in the same year as The Calculus of Consent. Three years later Mancur Olson's (1965) The Logic of Collective Action was published. Thus, by the mid-1960s several of the seminal contributions to this new literature had appeared, and the directions of future research could be discerned. Some work, following Arrow, would be analyzing how democratic processes ought to work, what normative properties they should satisfy. Others would be studying how democratic processes do in fact work, while still others would contain a bit of both. Virtually all of the contributions to this literature up to 1965 were theoretical. Econometrics had joined micro and macro economics in first year graduate economics programs by then, however, and so it would not be long before empirical studies of how democratic institutions operate began to appear.

The purpose of this short article is not to trace the evolution of this literature up to the present. To some extent I have done this already at least up to 2003. My narrower objective is to discuss the names people have given to the research agendas launched by Arrow, Downs, Buchanan and the others. Some have called it public choice, others social choice, still others political economy, or the new political economy. In the next section I look at the terms public choice and social choice. Section II discusses what is meant be the new political economy. Final Thoughts are offered in Section III.

\section{Public Choice and Social Choice}

In the 1960s, James Buchanan and Gordon Tullock were at the Thomas Jefferson Center for Political Economy at the University of Virginia. They organized a meeting of a small group of the pioneers working in this new area including Duncan Black and James Coleman. The papers presented at that meeting were published by the Thomas Jefferson Center in 1966 under the title, Papers on Non-Market Decision Making with Gordon Tullock 
as the editor. Thus, in the early days of this field of research its proper name might be viewed as either political economy, after the center that organized the first meetings, or non-market decision making, after the first publication of the papers presented at that meeting.

James Buchanan and Gordon Tullock exited from the University of Virginia at the end of the 1960s and soon regrouped at the Virginia Polytechnic Institute and State University in Blacksburg, Virginia. There they founded The Center for the Study of Public Choice. The occasional meetings initiated in the mid-1960s gave way to annual meetings of the Public Choice Society, and Papers on Non-Market Decision Making was replaced the journal Public Choice, a journal that has always been closely associated with the Public Choice Society. Thus, by the early 1970s the new area of research on democratic institutions had gotten a name - public choice - at least for a small, but rapidly growing group of scholars mostly located in the United States.

As the subject matter of public choice focused on political institutions, it was logical to open up the Public Choice Society to, and indeed to try to attract political scientists. Thus, essentially from its inception the Public Choice Society had a practice of alternating its presidency between an economist and a political scientist (in one case, James Coleman, a sociologist). In its early days, the political scientists who were attracted to the Public Choice Meetings were, within their discipline, somewhat non-mainstream. This changed over time as more and more political scientists began working with "rational actor models," as the public choice approach is often called in political science. Even in the 1970s and 1980s, however, it is difficult to call the leading scholars attending the Public Choice Society Meetings far removed from the mainstream. Two of the Society's past presidents were also elected presidents of the American Political Science Association, William Riker and Elinor Ostrom. One past president, James S. Coleman, was also elected president of the American Sociology Association. Three past presidents have won Nobel Prizes - James Buchanan, 
Vernon Smith, and Elinor Ostrom.

Despite the prestigious accomplishments of many members of the Public Choice Society, the term "public choice," when used to describe a body of research, appears to have obtained a connotation in some quarters of American academia as being non-mainstream. Among these scholars the label "social choice" is often preferred. Thus, for example, Amartya Sen, who won a Nobel prize for his work on problems of preference aggregation of the type Arrow studied, always refers to his research as social choice. ${ }^{\text {ii }}$ Later in this essay I want to explore why this is so, and whether the difference in labels carries with it differences in substance. But first I wish to briefly mention the migration of public choice to Europe and Japan.

The European Public Choice Society was started in the early 1970s by Elisabeth Liefmann-Keil, Bruno Frey, and Peter Bernholz. All three had visited the Public Choice Center in Blacksburg, and were excited by this new field of research and wished to bring it to Europe. Elisabeth Liefmann-Keil was the society's first president, 1972-74, and she was followed as president by Peter Bernholz, 1974-81. As with its American counterpart, the European Public Choice Society began with meetings of no more than 20 or so participants. Today it is a thriving society with annual meetings attracting 350 or more participants - more than its American counterpart is able to attract at this time. A somewhat similar story explains the creation of the Japanese Public Choice Society by Professor Hiroshi Kato following a visit to the Public Choice Center in Blacksburg. ${ }^{\text {iii }}$

Presumably anyone publishing an article in the journal, Public Choice, does not object to the article being called a contribution to the public choice literature. Thus, one way to judge the characteristics of those works that fall under the heading of public choice is to examine articles in the Public Choice journal. There is also a journal called Social Choice and Welfare and presumably contributors to that journal do not object to their work being 
labeled social choice. The two journals are in several ways quite similar. They are both published by Springer and have similar impact factors. In one such recent ranking, Public Choice was $175^{\text {th }}$ with an impact score of 3.605, and Social Choice and Welfare was $198^{\text {th }}$ with a score of 3.177. ${ }^{\text {iv }}$ By comparison the top ranked journal, The Quarterly Journal of Economics, had an impact factor of 53.996. The journals are also similar in that each is closely linked to a professional society of the same name. The Public Choice Society has been holding annual meetings for more than 40 years, the Social Choice and Welfare Society has held biannual meetings for more than 20 years.

To explore the differences in the two labels, public choice and social choice, I thus examined articles in the two journals which carry these names for the years 2009-2013. I omitted comments on other articles and corrections of previously published articles. I also excluded articles in special issues, since these often undergo a different selection and refereeing process. The remaining articles should be representative of the kinds of research submitted to and published in the two journals. The issues from which articles were selected are listed at the bottom of Table 1 . 
Table 1

Articles in Public Choice and Social Choice and Welfare, 2009-2013

\begin{tabular}{|c|c|c|}
\hline \multirow[b]{3}{*}{ Mathematical } & \multicolumn{2}{|c|}{ Articles } \\
\hline & Public Choice & Social Choice and Welfare \\
\hline & 0.334 & 0.918 \\
\hline Non-Mathematical & 0.058 & 0.006 \\
\hline Empirical & 0.575 & 0.025 \\
\hline Experimental & 0.034 & 0.050 \\
\hline \multirow[t]{2}{*}{ Total number } & 416 & 318 \\
\hline & \multicolumn{2}{|c|}{ Authors } \\
\hline USA/Canada & 0.381 & 0.231 \\
\hline European Union & 0.528 & 0.544 \\
\hline Other & 0.091 & 0.225 \\
\hline Total number & 756 & 592 \\
\hline
\end{tabular}

Notes: articles taken from the following issues:

Public Choice: 2013, March, April, June, July, Sept., Oct.

2012, Jan., March, June, Oct., Dec.

2011, Jan., March, April, June, July, Sept.

2010, Jan., April, July, Sept., Oct.

2009, Jan., March, April, June, July, Sept., Oct., Dec.

Social Choice and Welfare: 2013, Jan., Feb., March, April, June, July, Sept., Oct.

2012, Jan., Feb., March, June, Oct.

2011, Jan., Feb., June, July, Sept.

2010, Jan., Feb., March, April, June, July, Sept., Oct.

2009, Jan., Feb., March, May, June, Aug., Sept., Nov.

I examined a total of 416 articles in Public Choice and 318 in Social Choice and

Welfare. I assigned each article to one of four categories. The category labeled Mathematical refers to theoretical articles, which contain a considerable amount of mathematics. If an 
article contained a theoretical argument, but little or no mathematics, it was placed in the Non-Mathematical category. Some articles in this category also dealt with historical examples or policy discussions. Many of the empirical articles also contained a good deal of mathematics in deriving the model to be tested, but if I judged the main objective of the article to be testing one or more hypotheses, it was placed in the Empirical category. The fourth category contained articles presenting the findings from laboratory experiments.

The difference between the contents of the two journals is quite dramatic. Where almost 92 percent of the articles in Social Choice and Welfare were theoretical and mathematical, only a third of the articles in Public Choice fit this description. Only two of the 318 articles in Social Choice and Welfare were theoretical, but non-mathematical. Twenty-four of the articles in Public Choice, almost six percent of the total, fell into this category. Given the large differences in the fractions of theoretical contributions in the two journals, one expects and finds large differences in the fractions of empirical studies -57.5 percent in Public Choice as opposed to only 2.5 percent in Social Choice and Welfare. Neither journal published a large number of experimental studies during the five years under examination.

Returning to the distinction between positive and normative studies, we can postulate that a much larger fraction of the articles in Public Choice are positive in nature. While all theoretical contributions cannot be categorized as normative, all empirical studies are by definition positive in nature. Moreover, many of the articles in Social Choice and Welfare can be seen to be offering advice to a social planner, or maximizing some form of social welfare function. Thus, we can draw two conclusions from an examination of the content of these two journals.

1. Research in social choice tends to be more theoretical/mathematical than research in public choice. 
2. The focus in public choice is more on the positive analysis of political institutions and processes, while articles defining themselves as social choice are more likely to be normative.

The bottom half of Table 1 reports the countries in which the authors of the articles were located. When an author listed more than one affiliation, I chose the first one as the country of residence. What is perhaps most surprising in this portion of the table is that Europeans make up a majority of the authors in both journals. Indeed, the fractions of Europeans among the authors in the two journals are quite similar. I had expected North Americans to predominate in the Public Choice journal, given its origins and association with the American-based Public Choice Society. Europeans have, however, composed an increasing fraction of attendees at the Public Choice Society meetings in America, so perhaps I should not have been so surprised.

Social Choice and Welfare publishes more than twice the fraction of papers from authors outside of the USA/Canada and Europe as Public Choice does - 22.5 percent versus 9.1 percent. Within the Other category Japan and Israel dominate, but one can really say that contributions are coming from around the world - Australia and New Zealand, Taiwan, South Korea and China, Mexico and other Latin American countries. I have also included Russia in the other category.

\section{Public Choice and Political Economy}

In 2005, Daren Acemoglu published a review article of The Economic Effects of Constitutions by Torston Persson and Guido Tabellini (2003). This book was a follow-up to an earlier book of theirs (Persson and Guido Tabellini, 2000). In the first book, the authors used probabilistic voting models to derive predictions about the policy choices of various forms of democratic institutions - presidential systems, parliamentary systems, multi-party 
systems. The book under review by Acemoglu employed state of the art econometric techniques to test some of the predictions obtained from the modeling in the first book. Using the distinction between public choice and social choice made in the previous section, both books by Pedrsson and Tabellini would appear to fit more comfortably under the public choice heading than as social choice. The authors chose to call their first book a contribution to political economy, however, and Acemoglu employed the same term to describe their work. His article opens with the sentence, "Political economy has now emerged as an active and flourishing subdiscipline of economics," (Acemoglu, 2005, p. 1025). My concern is not with whether this type of research is best described as public choice or political economy, but with the word "now" in the sentence. It is possible that Acemoglu meant by the word "now" since the Second World, but one senses that he had a much shorter time frame in mind, judging from the other references in the article. Were Anthony Downs, James Buchanan, Gordon Tullock, Mancur Olson, William Riker and the other founders of the public choice not active enough for the field to be described as "flourishing" until the $21^{\text {st }}$ century?

Upon reading Acemoglu's article, James Buchanan reportedly became enraged at its cavalier treatment of previous research in the area. Anyone who spent much time with James Buchanan knows that when he got angry sparks flew and smoke rose to the heavens. I sympathize with his sense of injustice with Acemoglu's apparent dismissal of earlier work in public choice. One can, as I do, share with Acemoglu the view that the Persson and Tabellini "book deserves enthusiastic reception," without dismissing or implicitly disparaging prior contributions of a similar nature.

In the year following the publication of Acemoglu's article, The Oxford Handbook of Political Economy appeared, edited by Barry Weingast and Donald Wittman (2006). On the opening page, the editors define political economy in the following way, "In our view, political economy is the methodology of economics applied to the analysis of political 
behavior and institutions" (Weingast and Wittman, 2006, p. 3). On the opening page of Public Choice III appears the following definition, "Public Choice can be defined as the economic study of non-market decision making, or simply the application of economics to political science," (Mueller, 2003, p. 1). The same definition appears in the 1979 and 1989 editions of my Public Choice book. It would appear that what Weingast and Wittman call political economy and what I, and others, call public choice are essentially the same.

This impression is reinforced when one examines the topics covered in The Oxford Handbook of Political Economy and in Public Choice III, and the list of contributors to The Handbook. For example, I have always employed a broad conception of the domain of public choice, subsuming under it topics that many define as social choice. Thus, in Public Choice III there is a chapter on social welfare functions (Samuelson, Harsanyi, Bentham and Nash), a chapter on Arrow Paradoxes, and a chapter on Sen's Paretian liberal paradox. The Oxford Handbook of Political Economy also has a section labeled social choice, which contains three chapters. Although there are differences in emphasis between the two volumes, the overlap in the subject matter contained in Public Choice III and The Oxford Handbook of Political Economy is such as to force one to conclude that they are both dealing with the same set of topics and the same methodological approaches.

One reaches the same conclusion when one looks at the list of contributors to The Oxford Handbook of Political Economy. This list contains the names of several past presidents of the American Public Choice Society (Steven Brams, Geoffrey Brennan, James Buchanan, Bernard Grofman, Melvin Hinich, John Ledyard, Kenneth Shepsle), and one pastpresident of European Public Choice Society, Douglass Hibbs. Having been presidents of their respective societies, one assumes that none of these gentlemen would object to their work being labeled public choice instead of, or in addition to political economy. 


\section{Final Thoughts}

James Buchanan and Richard Musgrave were two towering figures in public economics over the second half of the $20^{\text {th }}$ century. They had such an impact on my own thinking that I dedicated a collection of my articles in public choice to the two of them (Mueller, 1993). Although both men were strongly influenced by Knut Wicksell's (1896) classic article, it is fair to say that they were polar opposites. Despite being educated in the United States and living there for most of his life, the German-born Musgrave retained a kind of European faith in the State as an institution for doing good. American-born Buchanan had a typically American distrust of the State, and concern about its capacity for doing bad. These differences were nicely brought out in a series of debates held in Munich (Buchanan and Musgrave, 1999).

This difference between Americans and Europeans is not new. Thus, in the nineteenth century we have the German historian, Heinrich von Treitschke observing that, "For us the state is not, as it is for the Americans, a power to be constrained so that the will of the individual may remain uninhibited, but rather a cultural power from which we expect positive achievements in all areas of national life.," Thus, in the aftermath of the 2008 financial crisis, with governments on both sides of the Atlantic facing huge budget deficits, members of the tea party movement in America protested for massive cuts in government spending, while across Europe citizens were protesting against cuts in spending.

This difference in perspective towards the state manifests itself in large portions of the public choice and social choice literatures. Although all contributors to the social choice literature are not Europeans, many of those who are European do seem to have a greater faith in the capacity and the likelihood of the state doing good than scholars working in public choice have, regardless of the latter group's location. This must be regarded as a salient difference between public choice and social choice, if one insists on distinguishing between 
them.

It would be difficult to design a form of social welfare function which, when maximized, led to the policy recommendation that the state should run a fiscal deficit for 40 consecutive years as France has done. Also, no self-respecting social planner would fudge the national account statistics to conceal a budget deficit the way politicians in Greece did. The gap between what social choice scholars say policy makers should be doing, and what they actually do often seems to be very large. No where is this gap more apparent than in the area of taxation. A huge number of articles have appeared in the area known as optimal taxation. This literature instructs the social planner how to minimize the excess burden of taxation, how to achieve horizontal and vertical equity, and more generally, how to maximize social welfare. The recommendations of the optimal tax literature come about as close to describing the actual tax code in the United States as Dorian Gray's portrait comes at the end of the novel to the original. ${ }^{\mathrm{vi}}$

In The Power to Tax, Geoffrey Brennan and James Buchanan (1980) presented a model of the state in which the state was a monopolist seeking to maximize its tax revenue. This book was roundly criticized for being a caricature of the state, but certainly modeling the state as a social planner maximizing a social welfare function is just as much of a caricature.

More generally, work in public choice has often been criticized for being too strongly "anti-state." Bureaucrats are seen as maximizing their budgets, the majority rule leads to excess spending, voting cycles abound. Those criticizing public choice for these sins, often argue that those running the state are trying to advance the public interest. ${ }^{\text {vii }}$ In fact, however, the realities in many democratic countries today, from Greece to California, are even worse than the picture of the state one draws from the public choice literature. A couple of years ago, I spent the winter quarter at the University of California in Santa Cruz. The discussion in the newspapers at that time was about how dysfunctional Sacramento was. Albany way 
also said to be dysfunctional, a former governor of Illinois was on his way to jail. Today, Detroit is in bankruptcy as are several cities in California. The U.S. Congress is not only incapable of advancing the public interest, it is incapable of doing anything.

While writing this paper, I have asked several people why they shy away from using the term public choice to describe their research. The answers I have sometimes received are that "public choice" has a right-wing connotation associated with it. People avoid its use, because of a kind of political correctness. This is unfortunate and a misrepresentation of the field. Many contributors to what I and I think most others would regard as the public choice literature, like Anthony Downs, Mancur Olson and Elinor Ostrom, were liberals in the American sense of the term. Although some of the leading figures in the public choice field could be characterized as political conservatives, this typically has not colored their research. Although examples of articles in public choice can be found where an author's political ideology has shown through and led to an embarrassingly bad argument, left-leaning scholars are not immune from writing ideologically tinged bad articles.

As my public choice books suggest, I take a rather ecumenical view of the field, which encompasses social choice as its practitioners think of it. As for political economy, if it is defined as Weingast and Wittman define it, than it is not only encompassed by public choice, it is indistinguishable from it. My closing advice to the profession is to worry less about the labels of the research that we do and concentrate more on its content.

\section{Endnotes}




\section{References}

Acemoglu, Daren, "Constitutions, Politics and Economics: A Review Essay of Persson and Tabellini's "The Economic Effects of Constitutions," Journal of Economic Literature, 43, Dec. 2005, pp. 1025-48.

Arrow, Kenneth J., Social Choice and Individual Values, 1951, revised edition, New York: John Wiley and Sons, 1963.

Black, Duncan, "On the Rationale of Group Decision Making," Journal of Political Economy, 56, February 1948a, pp. 23-34.

Black, Duncan, “The Decisions of a Committee Voting a Special Majority, Econometrica, 16, 1948b, pp. 245-61.

Brennan, Geoffrey and James M. Buchanan, The Power to Tax: Analytical Foundations of a Fiscal Constitution, Cambridge: Cambridge University Press, 1980.

Brennan, Geoffrey and James M. Buchanan, The Reason of Rules, Cambridge: Cambridge University Press, 1985.

Buchanan, James M., "Social Choice, Democracy, and Free Markets," Journal of Political Economy, 62, April, 1954a, pp. 114-23.

Buchanan, James M., "Individual Choice in Voting and the Market," Journal of Political Economy, 62, August, 1954b, pp. 334-43.

Buchanan, James M. and Richard A. Musgrave, Public Finance and Public Choice: Two Contrasting Views of the State, Cambridge MA: MIT Press, 1999.

Buchanan, James M. and Gordon Tullock, The Calculus of Consent, Ann Arbor MI: University of Michigan Press, 1962.

Burleigh, Michael, Earthly Powers, London: HarperCollins, 2005.

Downs, Anthony, An Economic Theory of Democracy, New York: Harper \& Row, 1957.

Hettich, Walter and Stanley L. Winer, Democratic Choice and Taxation, Cambridge: Cambridge University Press, 1999.

Lewin, Leif, Self-Interest and Public Interest in Western Politics, Oxford: Oxford University Press, 1991.

May, Kenneth O., "A Set of Independent, Necessary and Sufficient Conditions for Simple Majority Decision, Econometrica, 20, October 1952, pp. 680-4.

Mueller, Dennis C., The Public Choice Approach to Politics, Aldershot England: Edward Elgar, 1993.

Mueller, Dennis C., Public Choice III, Cambridge: Cambridge University Press, 2003.

Olson, Mancur, The Logic of Collective Action, New Haven CN: Yale University Press, 1965.

Persson, Torsten and Guido Tabellini, Political Economics - Explaining Economic Policy, Cambridge MA: MIT Press, 2000.

Persson, Torsten and Guido Tabellini, The Economic Effect of Constitutions, Cambridge MA: MIT Press, 2003. 
Riker, William H., The Theory of Political Coalitions, New Haven CN: Yale University Press, 1962.

Sen, Amartya K., "Rationality and Social Choice," American Economic Review, 85, March 1995, pp. 1-24.

Tullock, Gordon, “Some Problens of Majority Voting," Journal of Political Economy, 67, December, 1959, pp. 571-9.

Weingast, Barry B. and Donald A. Wittman, The Oxford Handbook of Political Economy, Oxford: Oxford University Press, 2006.

Wicksell, Knut, Finanztheoretische Untersuchungen; Jena: Gustav Fisher Verlag, 1896; English translation by James M. Buchanan, A New Principle of Taxation, in Richard A. Musgrave and Alan T. Peacock, eds., Classics in the Theory of Public Finance, New York: St. Martin’s Press, 1967.

i For a review of these models, see Mueller (2003, Ch. 12).

ii See, for example, "Amartya Sen - Biographical," http://www.nobelprize.org/nobel_prizes/economic-sciences/laureates/1998/senbio.html, (accessed Dec. 3, 2013) and his presidential address to the American Economic Association (Sen, 1995).

iii See, discussion by Professor Akihito Udagawa, who was also greatly influenced by his visit to the Center. http://publicchoice.info/Buchanan/files/udagawa.htm, accessed Dec. 3, 2013.

iv See, http://ideas.repec.org/top/top.journals.simple.html, accessed Dec. 4, 2013.

v As quoted in Burleigh (2005, p. 327).

vi For a public choice analysis of taxation, see Hettich and Winer (1999).

vii See, for example, Lewin (1991). 